\title{
Intravascular histiocytosis associated with rheumatoid arthritis
}

\author{
Romatoid artrit ile ilişkili intravasküler histiyositoz
}

\author{
Nilay Şen Türk*, Neşe Çallı Demirkan*, Levent Taşlı**, Necibe Yıldız** \\ *Pamukkale Üniversitesi, Tıp Fakültesi Patoloji AD, Denizli \\ **Pamukkale Üniversitesi, Tıp Fakültesi Dermatoloji AD, Denizli
}

\begin{abstract}
Various dermatoses associated with rheumatoid arthritis (RA). have been described Recently, a specific skin lesion termed "intravascular histiocytosis" has been proposed as a new entity among these dermatoses. We report a 58-year-old man with an 8-years history of RA who presented with numerous variable sized erythematous papules, plaques and nodules on the $\mathrm{V}$ region of the neck, right femoral region and bilateral shins. Histopathological examination of these lesions demonstrated intraluminal aggregates mainly composed of CD68-positive histiocytes in markedly dilated vessels. In addition, after 6 months of follow-up, the patient was diagnosed as Kaposi sarcoma (KS) for another skin lesion. We discuss the pathogenesis of this association and compare with other cases reported in the literature.
\end{abstract}

Pam Med J 2013;6(2):92-95

Key words: Histiocytosis, Rheumatoid Arthritis

Özet

Romatoid artrit (RA) ile ilişkili çeşitli dermatozlar tanımlanmaktadır. Son zamanlarda, "intravasküler histiyositoz" olarak isimlendirilen spesifik deri lezyonu, bu dermatozlar arasında yeni bir antite olarak öne sürülmektedir. Biz, boyun V bölgesi, sağ femoral bölge ve bilateral bacaklarda çeşitli boyutlarda çok sayıda eritematöz papül, plak ve nodüllerle başvuran 8 yıllık RA öyküsüne sahip 58 yaşında erkek hasta rapor ettik. Bu lezyonların histopatolojik incelemesinde, belirgin şekilde dilate damarlarda, başlıca CD68-pozitif histiyositlerden oluşan intralüminal topluluklar izlendi. Ek olarak, hasta 6 ay sonra bir başka deri lezyonundan Kaposi Sarkomu tanısı aldı. Biz, bu birlikteliğin patogenezini literatürde rapor edilen diğer olgularla karşılaştırarak tartıştık.

Pam Tıp Derg 2013;6(2):92-95

Anahtar sözcükler: Histiyositoz, Romatoid Artrit

\section{Introduction}

Rheumatoid arthritis (RA) is an autoimmune systemic inflammatory disease. Its primary manifestations present in the synovium of joints that has a propensity to affect the small joints of the hands and feet with extra-articular manifestations comprising skin lesions [1,2]. The prototypic skin lesion is the rheumatoid nodule [1]. Other skin dermatoses are uncommon and defined histopathologically rather than clinically $[1,3]$. These dermatoses include vasculitis, rheumatoid papules, rheumatoid neutrophilic dermatosis, superficial ulcerating rheumatoid necrobiosis, neutrophilic lobular panniculitis, erythema nodosum-like lesions, digital purpuric papules, diffuse interstitial and palisading granulomatous dermatitis and pyoderma gangrenosum [1,4]. Recently, a specific skin lesion termed "intravascular or intralymphatic histiocytosis" has been proposed as a new entity among these dermatoses [5-7]. We present a case of intravascular histiocytosis associated with RA with distinct clinical and histopathological features.

\section{Case}

A 58-year-old man had an 8-year-history of seropositive RA and a 3-year-history of hypertension. The ankles were predominantly affected. He was being treated with prednisolone, methotrexate, leflunomide, and

Nilay Şen Türk

Yazışma Adresi: Pamukkale Üniversitesi, Tıp Fakültesi Patoloji AD, Denizli

e-mail: sennilay@hotmail.com

Gönderilme tarihi: 18.09.2012

Kabul tarihi: 14.02 .2013 
hydroxychloroquine sulfate, naproxen for RA and atenolol + chlorthalidone for hypertension during this period.

He presented with a 1-year-history of asymptomatic erythematous patches. The examination revealed bright erythematous plaques with distinct demarcation between 0,5 and $1 \mathrm{~cm}$ in diameter on the $V$ region of the neck. A total of 4-5 bright erythematous nodules, $5 \times 5 \mathrm{~mm}$ in diameter were noted on his right femoral region (Figure 1). In addition, there were numerous variable sized erythematousvioleaceous papules and plaques involving the shins bilaterally and brown-black-colored hyperkeratotic plaques on first and second metatarsal phalangeal joint region of foot dorsum. Other physical examination revealed no abnormal findings.

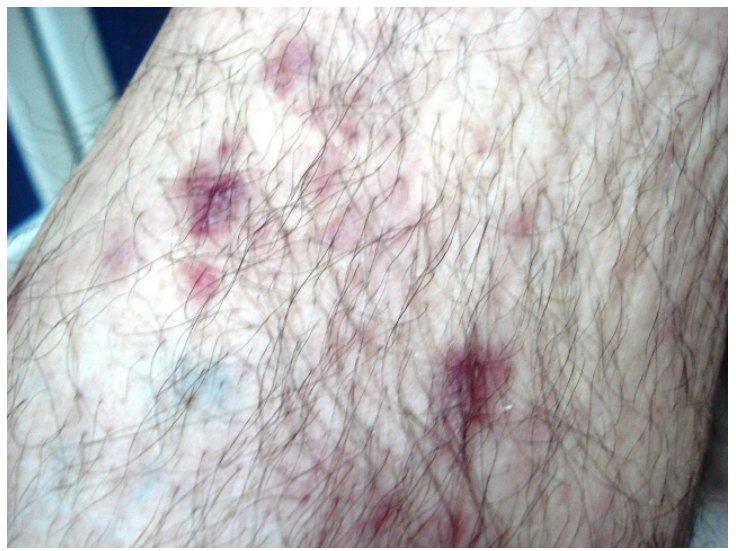

Figure 1. Multiple erythematous papules and nodules on the shin.

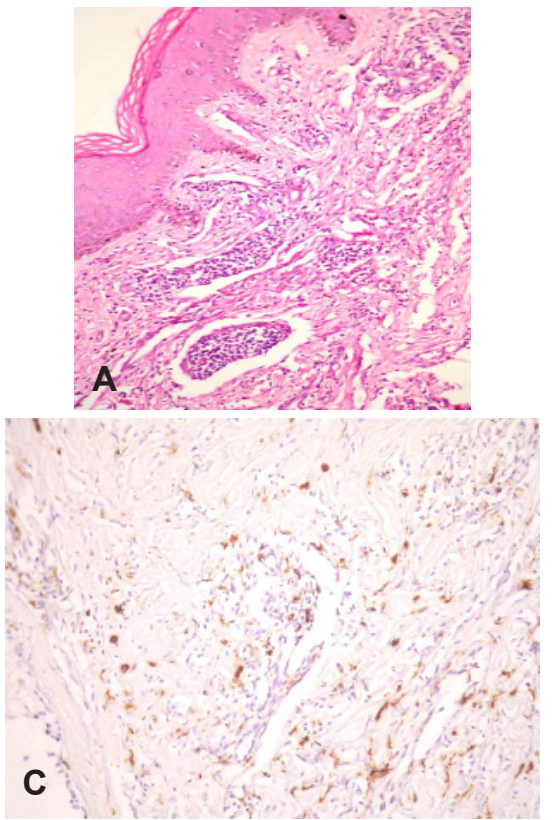

Laboratory examinations revealed elevated levels of erythrocyte sedimentation rate (36 $\mathrm{mm} / \mathrm{h})$, C-reactive protein $(3,6 \mathrm{mg} / \mathrm{dL})$ and rheumatoid factor $(81,5 \mathrm{IU} / \mathrm{mL})$. Other laboratory tests including complete blood count, renal and liver function tests were within normal limits.

An incisional biopsy from the cutaneous lesions on his right femoral region was performed. It revealed normal epidermis and markedly dilated dermal vessels filled with predominantly histiocytic cells (Figure 2a-b). These intravascular histiocytic cells and endothelial cells showed no nuclear atypia or mitosis. In addition, small mature lymphocytes, histiocytes and neutrophils were present in the surrounding stroma as well as intravascular space. Intravascular histiocytic cells showed positive staining with CD68 (Figure 2c). Endothelial cells lining the dilated vessels showed positive staining with CD31 and CD34 (Figure 2d). No organism was identified in sections stained with PAS, Ziehl-Nielsen or Gram stain. A diagnosis of intravascular histiocytosis associated with RA was made.

The patient was treated with topical corticosteroid ointment; however, his skin lesions showed no regression during six months. After 6 months of follow-up, the patient was diagnosed as Kaposi sarcoma (KS) for skin lesion on the first and second metatarsal phalangeal joint region of foot dorsum with lung metastasis at another hospital. At six months of follow-up the patient died. However; an autopsy was not performed.

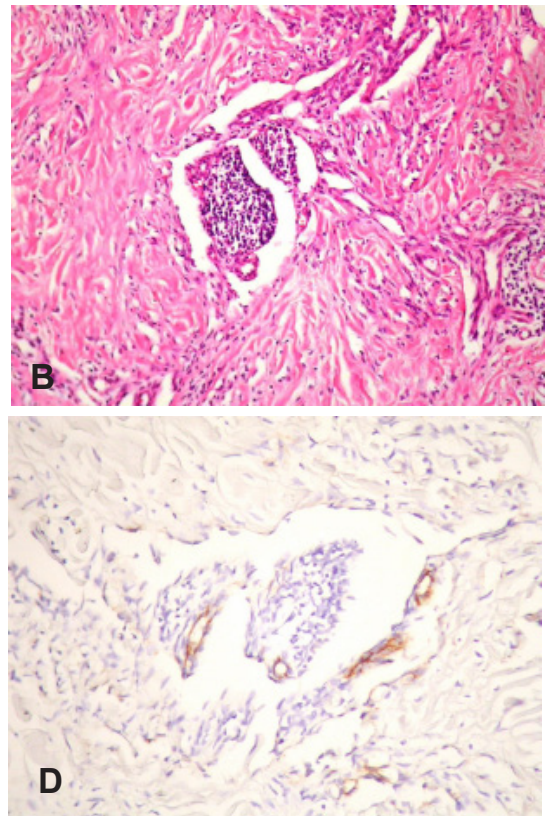

Figure 2. Skin biopsy showed A: numerous irregular dilated vessels throughout the dermis (Heamatoxylene-eosine, $x$ 200) and B: aggregation of histiocytes in the lumina of these vessels (Heamatoxylene-eosine, x 400). C: Intraluminal and perivascular cells were CD68-positive histiocytes (x 400). D: Endothelial cells lining the dilated vessels were positive for CD34 (x 400). 


\section{Discussion}

A wide spectrum of cutaneous dermatoses has been described in association with RA [1]. Recently, chronic erythematous lesions in the vicinity of involved joints in several patients with RA have been reported as an "intravascular histiocytosis" because of their specific histopathological findings [8]. Histopathologically, intravascular histiocytosis is characterized by the proliferation of histiocytes in the dilated blood or lymphatic vessels [3,9]. This rare disorder was firstly described by O'Grady et al. in 1994 [9]. However, these reported cases have used different terms, involving intravascular histiocytosis, cutaneous histiocytic lymphangitis and intravascular or intralymphatic histiocytosis $[2,3,8,10]$. Also similar skin lesions were named angioendotheliomatosis with rheumatoid arthritis [4]. Furthermore, Rieger et al suggested that intravascular histiocytosis might be the early stage of reactive angioendotheliomatosis [10]. Rare cases of intravascular histiocytosis presenting with a clinical and histologic picture similar to that of reactive angioendotheliomatosis but showing intravascular cells with a histiocytic immunophenotype have been described $[3,11]$. To date, we found twelve other published cases in the English literature that fitted the term "intravascular or intralymphatic histiocytosis associated with RA" (Table 1).

Table 1. Summary of documented intravascular histiocytosis associated with rheumatoid arthritis

\begin{tabular}{|c|c|c|c|c|c|}
\hline Case No & $\begin{array}{l}\text { Age/ } \\
\text { Sex }\end{array}$ & Clinical features & Location & Histopathology & $\begin{array}{l}\text { History of } \\
\text { RA }\end{array}$ \\
\hline 1. Pruim et al (2). & $63 / \mathrm{M}$ & $\begin{array}{l}\text { Violaceous lesion with } \\
\text { livedo-like erythema }\end{array}$ & Elbow & $\begin{array}{l}\text { Intralymphatic collections } \\
\text { of histiocytes }\end{array}$ & 15 years \\
\hline 2. Pruim et al (2). & $59 / F$ & Erythematous rash & Wrist & $\begin{array}{l}\text { Intralymphatic collections } \\
\text { of histiocytes }\end{array}$ & 13 years \\
\hline 3. Takiwaki et al (3). & $69 / F$ & $\begin{array}{l}\text { Indurated erythema and } \\
\text { papules }\end{array}$ & Elbow & $\begin{array}{l}\text { Intravascular or intralym- } \\
\text { phatic histiocytosis }\end{array}$ & 2 years \\
\hline 4. Takiwaki et al (3). & $74 / \mathrm{M}$ & $\begin{array}{l}\text { Partly livedo-like irregular } \\
\text { erythema }\end{array}$ & Elbow, forearm & $\begin{array}{l}\text { Intravascular or intralym- } \\
\text { phatic histiocytosis }\end{array}$ & 3-4 years \\
\hline 5. Takiwaki et al (3). & $66 / M$ & Livedo-like erythema & Elbow, forearm & $\begin{array}{l}\text { Intravascular or intralym- } \\
\text { phatic histiocytosis }\end{array}$ & 11 years \\
\hline 6. Takiwaki et al (3). & $62 / F$ & $\begin{array}{l}\text { Erythema with confluent } \\
\text { papules }\end{array}$ & Forearm & $\begin{array}{l}\text { Intravascular or intralym- } \\
\text { phatic histiocytosis }\end{array}$ & 5 years \\
\hline $\begin{array}{l}\text { 7. Catalina-Fernan- } \\
\text { dez et al (5). }\end{array}$ & $50 / F$ & Erythematous patches & Lower leg & $\begin{array}{l}\text { Intralymphatic histiocyto- } \\
\text { sis }\end{array}$ & 10 years \\
\hline 8. Huang et al (6). & $71 / \mathrm{F}$ & $\begin{array}{l}\text { Irregular erythematous } \\
\text { oedematous patches }\end{array}$ & $\begin{array}{l}\text { Forearms near } \\
\text { the elbows }\end{array}$ & Intravascular histiocytosis & 25 years \\
\hline 9. Nishie et al (7). & $49 / F$ & Livedo-like erythema & Elbow, forearm & Intravascular histiocytosis & 5 years \\
\hline 10. Okazaki et al (8). & $52 / \mathrm{M}$ & $\begin{array}{l}\text { Livedo-like erythema with } \\
\text { vesicles }\end{array}$ & Lower leg & $\begin{array}{l}\text { Intravascular histiocytosis } \\
\text { with lymphatic endothelial } \\
\text { hyperplasia }\end{array}$ & 1.5 years \\
\hline 10. Rieger et al (10). & $77 / F$ & $\begin{array}{l}\text { Violaceous patches with } \\
\text { livedo-like erythema }\end{array}$ & Elbow & Intravascular histiocytosis & $\begin{array}{l}\text { Yes (duration } \\
\text { unknown) }\end{array}$ \\
\hline $\begin{array}{l}\text { 11. Okamoto et al } \\
\text { (12) }\end{array}$ & $75 / F$ & Infiltrated erythema & Left forearm & $\begin{array}{l}\text { Intralymphatic histiocyto- } \\
\text { sis }\end{array}$ & 20 years \\
\hline 12. Present case & $58 / \mathrm{M}$ & $\begin{array}{l}\text { Erythematous papules, } \\
\text { plaques and nodules }\end{array}$ & Lower extremity & Intravascular histiocytosis & 8 years \\
\hline
\end{tabular}

RA, rheumatoid arthritis; $F$, female; $M$, male.

The sex ratio was $1 / 2$ (male: 4 , female: 8 ) in these cases. The mean age at presentation was 64 years (range, 49-77). The most common localization of lesions were elbow, forearm, lower leg and wrist. Mean duration of RA at presentation was 10 years (range, 1,5-25).
Clinical features of these cases were highly variable.

Histopathologically, chronic erythematous lesions showed features of histiocytic aggregation in dilated dermal vessels $[3,8,10]$. 
It was demonstrated that the vessels were lined by endothelial cells expressing either factor VIII-related, CD31 or CD34 antigens and predominant intraluminal cells were CD68positive histiocytes $[5,7,8]$. The irregularly and significantly dilated vessels with thin walls in the dermis are reminiscent of lymphatic structure than blood vessels. By immunohistochemistry, a monoclonal antibody D2-40 stains the endothelial cells of lymphatic vessels, however, it does not stain histiocytes and other blood vessels [8].

The pathogenesis of this unusual cutaneous lesion is still uncertain. Pruim et al suggested that the cutaneous lesions might represent lymphatic drainage of inflammatory components away from inflamed synovium and not be specifically related to RA [2]. Reactive intravascular histiocytosis associated with RA has a benign nature, but these lesions are relatively resistant to topical and systemic therapies and show a prolonged clinical course $[7,8]$. Our patient was diagnosed as $\mathrm{KS}$ for skin lesion on the first and second metatarsal phalangeal joint region of foot dorsum with lung metastasis after 6 months of follow-up. To our knowledge, there has been no documented case of $\mathrm{KS}$ in association with intravascular histiocytosis in a RA patient. KS may arise in association with many causes of immunodeficiency [11]. Despite recent advances in knowledge regarding the etiology and pathogenesis of $\mathrm{KS}$, there remain many unusual facets about the disease that as yet defy adequate scientific explanation. It is still controversial whether KS is a multifocal reactive process or a neoplastic condition [11]. We suggested that a possible cause of the KS in our patient may be immunodeficiency owing to the treatment of RA. Intravascular histiocytosis is an ill-defined entity, but clinicians and pathologists should remain mindful of these skin lesions. Because, persistent treatment-resistant disease course and its histopathology mimic other diseases including intravascular lymphoma and other vascular lesions [7,8]. Pathologists should be aware that chronic erythematous skin lesions demonstrating intravascular aggregation of histiocytes may develop in the vicinity of swollen joints of patients with RA.

\section{References}

1. Magro CM, Crowson AN. The spectrum of cutaneous lesions in rheumatoid arthritis: a clinical and pathological study of 43 patients. J Cutan Pathol 2003;30:1-10.

2. Pruim B, Strutton G, Congdon S, Whitehead K, Donaldson E. Cutaneous histiocytic lymphangitis: an unusual manifestation of rheumatoid arthritis. Australas J Dermatol 2000;41:101-105.

3. Takiwaki H, Adachi A, Kohno H, Ogawa Y. Intravascular or intralymphatic histiocytosis associated with rheumatoid arthritis: a report of 4 cases. J Am Acad Dermatol 2004;50:585-590.

4. Tomasini C, Soro E, Pippione M. Angioendotheliomatosis in a woman with rheumatoid arthritis. Am J Dermatopathol 2000;22:334-338.

5. Catalina-Fernández I, Alvárez AC, Martin FC, Fernández-Mera JJ, Sáenz-Santamaría J. Cutaneous intralymphatic histiocytosis associated with rheumatoid arthritis: report of a case and review of the literature. Am J Dermatopathol 2007;29:165-168.

6. Huang HY, Liang CW, Hu SL, Cheng CC. Cutaneous intravascular histiocytosis associated with rheumatoid arthritis: a case report and review of the literature. Clin Exp Dermatol 2009;34:e302-e303.

7. Nishie W, Sawamura D, Litoyo M, Shimizu H. Intravascular histiocytosis associated with rheumatoid arthritis. Dermatology 2008;217:144-145.

8. Okazaki A, Asada H, Niizeki H, Nonomura A, Miyagawa S. Intravascular histiocytosis associated with rheumatoid arthritis: report of a case with lymphatic endothelial proliferation. $\mathrm{Br} \mathrm{J}$ Dermatol 2005;152:1385-1387.

9. O'Grady JT, Shahidullah H, Doherty VR, al-Nafussi A. Intravascular histiocytosis. Histopathology 1994;24:265-268.

10. Rieger E, Soyer HP, Leboit PE, Metze D, Slovak $\mathrm{R}$, Kerl $\mathrm{H}$. Reactive angioendotheliomatosis or intravascular histiocytosis? An immunohistochemical and ultrastructural study in two cases of intravascular histiocytic cell proliferation. $\mathrm{Br} J$ Dermatol 1999;140:497-504.

11. Calonje E. Vascular tumors. tumors and tumorlike conditions of blood vessels and lymphatics. In: Elder DE, Elenitsas R, Johnson BL, Murphy GF, Xu X, eds. Lever's Histopathology of the Skin. 10th ed. Philadelphia: Lippincott-Williams\&Wilkins, a Wolters Klumer Business, 2009;1008-1035.

12. Okamoto N, Tanioka M, Yamamoto T, Shiomi T, Miyachi Y, Utani A. Intralymphatic histiocytosis associated with rheumatoid arthritis. Clin Exp Dermatol 2008;33:516518. 